\title{
POTENTIAL FOR PHYTOREMEDIATION OF IRON CYANIDES USING WILLOW'
}

\author{
by
}

\author{
Mari K. Reeves ${ }^{2}$, Leonard Weinstein, John Laurence, and Paul King
}

\begin{abstract}
Metal cyanide complexes, particularly iron cyanides, are byproducts of leaching of gold and silver ores, aluminum smelting, and gas manufacture from coal. Disposal of wastes from ore and coal processing has led to extensive soil and ground water contanination by iron cyanides in former mining and industrial areas. A series of studies evaluated the ability of plants to absorb or degrade iron cyanides, as preliminary evidence for the potential for phytoremediation of lands contaminated by iron cyanide compounds.
\end{abstract}

Additional Key Words: phytoremediation, hexacyanoferrate, ferrocyanide, ferricyanide, cyanide, Salix.

First, five plant species found at a site of former gas manufacture were evaluated for tolerance to three different concentrations of hexacyanoferrate ion $(0,30$, and $143 \mathrm{mg}$ hexacyanoferrate ion $\mathrm{l}^{-1}$ ) for approximately 25 days in aerated hydroponic solutions. The species evaluated included a willow (Salix eriocephala), wild cane (Gynerium sp.), purple loosestrife (Lythrum salicaria), a grass (Setaria sp.), and a sedge (Scirpus sp.).

The high hexacyanoferrate concentration was highly toxic or lethal to the grass, the loosestrife, and the wild cane with in two weeks or less, but the sedge seedlings and willow cuttings exhibited no foliar symptoms after 2 weeks. After 25 days, the fresh and dry biomass of the sedge was reduced significantly by the hexacyanoferrate treatments, but the willow was affected only slightly at the end of the experiment. The willow and the sedge had the highest survival rate and the highest biomass production of the five tested species over the course of the experiment.

Second, willows taken from a single parent plant at the gas manufacture site were tested to evaluate whether the plants could remove hexacyanoferrate from hydroponic solution. In this experiment, the willows effected a $75 \%$ removal of hexacyanoferrate from solutions,

${ }^{1}$ Poster presented at the 2001 National Meeting of the American Society for Surface Mining and Reclamation, Albuquerque, New Mexico, June 3-7, 2001. Publ. By ASSMR, 3134 Montavesta Rd., Lexington, KY 40502.

2 Mari Reeves, Research Associate, Reclamation Research Unit, Montana State University, Bozeman, MT 59717. Leonard Weinstein, John Laurence, and Paul King, Boyce Thompson Institute for Plant Research, Tower Road, Ithaca, NY 14853. compared with a $25 \%$ removal rate by non-plant controls. Additionally, nitrogen contents and natural abundance isotope ratios of the leaves differed between plants treated with hexacyanoferrate and plants supplied with only $\mathrm{NH}_{4}^{+}$and $\mathrm{NO}_{3}{ }^{-}$nitrogen. It is unclear whether observed hexacyanoferrate removal was due to plant uptake or degradation of the compound, or to rootmediated precipitation of insoluble iron cyanide complexes on the root surface. Nonetheless, it is clear from these experiments that the hexacyanoferrate removal was somehow plant mediated.

Third, we used ${ }^{15} \mathrm{~N}$-labeled hexacyanoferrate (II) to establish whether or not the willow plants were translocating the nitrogen from hexacyanoferrate into leaf tissue. Clones of a single parent plant of Salix eriocephala Michx were grown hydroponically in the greenhouse and treated with $6 \mathrm{mg}$ cyanide $1^{-1}(8 \mathrm{mg}$ $\left.\left[\mathrm{Fe}(\mathrm{CN})_{6}\right]^{\mathrm{x}-\mathrm{r}^{-1}}\right)$ as a mixture of ${ }^{15} \mathrm{~N}$-labeled $\mathrm{K}_{4} \mathrm{Fe}\left(\mathrm{C}^{15} \mathrm{~N}\right)_{6}$, unlabeled $\mathrm{K}_{4} \mathrm{Fe}(\mathrm{CN})_{6}$, and $\mathrm{K}_{3} \mathrm{Fe}(\mathrm{CN})_{6} \quad(95: 5$ hexacyanoferrate (II): hexacyanoferrate (III) ratio in nutrient solution). Each experiment consisted of three treatments: (1) a control in $20 \%$ Johnson's nutrient solution with no hexacyanoferrate, (2) A treatment with hexacyanoferrate in $20 \%$ Johnson's solution (including iron-EDTA) and (3) A treatment with hexacyanoferrate in otherwise iron-free $20 \%$ Johnson's solution (without iron-EDTA). After 10 to 23 days of treatment, destructive harvest of plants and subsequent isotopic analysis of leaf tissue indicated that plants translocated nitrogen from iron-cyanide to leaves; only leaves were analyzed. All treated plants incorporated the nitrogen from hexacyanoferrate (II) into leaf tissue. Uptake of nitrogen from the iron cyanide was greater in plants deprived of iron than it was in plants supplied with sufficient iron in the nutrient solution. Calculations based on the content of hexacyanoferrate-derived ${ }^{15} \mathrm{~N}$ in the willow leaves suggest that the willow plants can degrade averages of 28 and $43 \mathrm{mg}\left[\mathrm{Fe}(\mathrm{CN})_{6}\right]^{\mathrm{x}-}$ per $\mathrm{m}^{2}$ of 
leaf area per week; the averages are for plants supplied with iron and deprived of iron, respectively. Plant survival was $100 \%$, but $\left[\mathrm{Fe}(\mathrm{CN})_{6}\right]^{\mathrm{x}-}$ treated plants suffered reductions in water use $(42 \%)$, leaf area $(54 \%)$, leaf mass (35\%), and root mass (49\%) over untreated controls. All treated plants in the third experiment accumulated anthocyanin in leaf tissues. Anthocyanin is a red pigment, which can serve as protection for the photosynthetic apparatus while the plant is stressed.
These studies indicate that willow plants have potential for use in phytoremediation of lands contaminated by iron cyanides from mining and industry. Although it has not been shown that plants absorb or degrade the hexacyanoferrate ion, these three experiments give strong evidence that (1) willows are tolerant to iron cyanides in solution, (2) degradation of iron cyanide compounds is plant mediated and (3) plants absorb the nitrogen from the hexacyanoferrate ion and translocate that nitrogen into leaf tissue. 